ISSN 1392-3196 / e-ISSN 2335-8947

Zemdirbyste-Agriculture, vol. 101, No. 3 (2014), p. 321-326

DOI 10.13080/z-a.2014.101.041

\title{
Potential effect of seed fatty acid profile of pepper (Capsicum annuum L.) cultivars on germination at various temperatures
}

\author{
Haluk Çağlar KAYMAK \\ Atatürk University \\ 25240 Erzurum, Turkey \\ E-mail: hckaymak@atauni.edu.tr
}

\begin{abstract}
The present study was undertaken to determine the fatty acid profile of seeds of pepper (Capsicum annuum L.) cultivars 'Yağ', 'Çetinel-150' and 'Bağcı Çarliston' as well as the relations between fatty acid profile, seed germination and vigour at various temperatures $\left(15,25\right.$ and $\left.35^{\circ} \mathrm{C}\right)$. In this study, the germination percentage and vigour, total oil and the fatty acid profile of seeds of pepper cultivars were determined. There were significant differences in seed germination and vigour among the cultivars. Linoleic (C18:2n-6) acid was the principal fatty acid followed by palmitic $(\mathrm{C} 16: 0)$, oleic $(\mathrm{C} 18: 1 \mathrm{n}-9)$ and stearic $(\mathrm{C} 18: 0)$ acids in all cultivars. The highest concentrations of linoleic $(77.8 \%)$, oleic $(10.4 \%)$, palmitic $(10.6 \%)$ and stearic $(2.5 \%)$ acids were determined in the cultivars 'Çetinel-150', 'Yağ' and 'Bağcı Çarliston', respectively, and miristic, margaric, gadoleic and behenic acids at an even lower content $(<1 \%)$. In addition to simple correlation coefficients $(r)$ between the total oil, fatty acid composition, and germination percentage and vigour of the pepper cultivars, similar results were obtained in stepwise multiple regression analysis. According to the stepwise multiple regression analysis, although results for vigour were similar to the results of germination, in addition to linoleic acid, the indirect effect of miristic, margaric, palmitoleic and gadoleic acids were determined for vigour. Research results demonstrated that the low or high amount of fatty acids in the tested cultivars may play a major role on germination and vigour at various temperatures. Moreover, the role of linoleic acid (C18:2n-6) on germination and vigour associated with temperature was more explicit than that of the other fatty acids.
\end{abstract}

Key words: emergence, linoleic acid, Solanaceae, temperature stress, viability.

\section{Introduction}

Pepper (Capsicum spp.) is a warm-season crop that belongs to the Solanaceae family. Due to its tropical origin, it is chilling-sensitive and cannot tolerate extended periods of temperatures below $10^{\circ} \mathrm{C}$ without serious metabolic disruptions (Decoteau, 2000). The seed germination range of pepper types is between $15^{\circ} \mathrm{C}$ and $35^{\circ} \mathrm{C}$, with an optimum soil temperature of about $30^{\circ} \mathrm{C}$. Seed germination of pepper has proved to be very slow and erratic, and this is a common phenomenon in pepper seeds especially under stressful conditions (Sarıyıldiz et al., 2005). Seeds are sowed in the early spring at low temperatures for production in the open field, and in late summer at higher temperatures for production in the Mediterranean region has great importance for seedling establishment forvegetable crops such as pepper. Sarıyldiz et al. (2005) reported that one special feature expected of high quality seeds is to be able to germinate under stressful growing conditions or production areas. Vegetable seed quality depends on many factors including moisture content, germination level, pathogen contamination, varietal purity and physical integrity and a complex series of metabolic processes such as water imbibition, respiration, mobilization of food reserves such as lipids, nucleic acid and protein synthesis, cell differentiation and growth play a major role for germination (Wanasundara et al., 1999). While little information was available in literature concerning the effect of lipids and fatty acids on germination under adverse or stressful conditions in peppers, it was reported that low or high amount of fatty acids such as miristic (C14:0), oleic (C18:1n-9), linoleic (C18:2n-6) and arachidic (C20:0) acids played a major role on germination percentage and rate in cucurbits (Kaymak, 2012).

Although a number of papers exist regarding the characterization of the seeds oils and fatty acid composition of different vegetable crops' seeds (Barthet, 2008; Mortley et al., 2012; Jarret et al., 2013), most do not cover the relations between fatty acid composition and seed germination and vigour under stressful temperatures. Therefore, the present study was undertaken to determine the fatty acid profile of seeds of pepper (Capsicum annuum L.) cultivars, as well as the relations between fatty acid profile, seed germination and vigour under controlled conditions.

\section{Materials and methods}

This study was conducted in growth chambers and gas chromatography-mass spectrometry laboratory in Atatürk University in 2011 and 2012 to determine the potential effect of fatty acid (FA) composition on seed germination and vigour of pepper (Capsicum annuum L.) cultivars 'Yağ', 'Çetinel-150' and 'Bağcı Çarliston' at various temperatures. In this study, two-year old pepper 
seeds were used as plant material. The seeds were supplied by a Turkish seed company Toros Agri-Industry and Trade Corporation. All the cultivars' seeds tested in this study were the product of 2010 and the same company because various factors including harvest time, level of maturity, seasonal variation, drying conditions, variety, cultivar and source of seeds, soil properties of seed production area and storage conditions of seeds may be affected the properties of seeds such as fatty acids (Kaymak, 2012).

Germination tests were carried out using four replicates of 50 seeds, disinfested in $1 \%$ sodium hypochlorite for $15 \mathrm{~min}$ to eliminate seed born microorganisms, from each cultivar in $9 \mathrm{~cm}$ Petri dishes in the dark. They were placed in a growth chamber for a period of 14 days (ISTA, 1996), at 15,25 and $35^{\circ} \mathrm{C}$. The seeds were incubated between two filter papers saturated with water containing benomyl (Methyl-1(butylcarbamoyl)-2-benzimidazole carbamate, 50\%) $1 \mathrm{~g}$ $\mathrm{I}^{-1}$ to prevent fungal growth.

Visible-radicle protrusion, $2 \mathrm{~mm}$ length of radicle, was the criterion of germination (Güvenç, Kaymak, 2006; Demir et al., 2008). Germinated seeds were recorded and discarded at 24 hour intervals during 14 days (ISTA, 1996) and the results were expressed as final germination percentage.

Vigour tests were conducted using four replicates of 50 seeds of each cultivar and seeds were sown $1 \mathrm{~cm}$ deep in standard plastic pots $(11 \times 20 \times 7 \mathrm{~cm})$ in a soilless medium ( $75 \%$ sphagnum peat and $25 \%$ perlite). Plastic pots were placed in a growth chamber maintained at $15 \pm$ $1,25 \pm 1$ and $35 \pm 1{ }^{\circ} \mathrm{C}$ for a period of four weeks. They were irrigated and inspected daily. Seed vigour reflects the seedling emergence (Matthews et al., 2009) and the emerged seedlings were counted daily until no further seedlings appeared. At the end of the vigour test, the total number of emerged seedlings in each plastic pot was determined and expressed as a final vigour percentage.

Germination and vigour tests were conducted in a randomized complete block design including four replications. The data were subjected to ANOVA and means were compared by using Duncan's multiple range test. Arcsin transformation was made for percentage data before statistical analysis. Additionally, stepwise multiple regression and the correlation coefficients $(r)$ between fatty acid profile and germination percentage and vigour were determined for all temperatures.

Lipid extraction of seeds of pepper (Capsicum annuum L.) cultivars (c. $1 \mathrm{~g}$ ) was made according to Folch et al. (1957). According to this method, the samples were homogenized in chloroform/methanol $(2: 1 \mathrm{v} / \mathrm{v})$ containing $0.01 \%(\mathrm{w} / \mathrm{v})$ of butylated hydroxytoluene (Sigma, $\geq 99.0 \%$ gas chromatography, B1378) as antioxidant $20 \mathrm{vol}$. (w/v) for $1 \mathrm{~min}$. Homogenization was performed in ice and other mediums (filtration, incubation, etc.) at $20-22^{\circ} \mathrm{C}$. The organic solvent was evaporated under a stream of nitrogen and the amount of lipid was determined gravimetrically. Fatty acid methyl esters (FAMEs) were prepared from lipids according to the method of Metcalfe and Schmitz (1961). The crude lipid extract was saponified with $\mathrm{NaOH}$ in methanol and FAMEs were prepared by transmethylation with boron trifluoride $\left(\mathrm{BF}_{3}\right)$ in methanol. Fatty acid methyl esters were gained by means of a "Hewlet Packard" Agilent $6890 \mathrm{~N}$ model gas chromatography, which has a flame ionization detector and suited with a DB 23 capillary column $(60 \mathrm{~m}, 0.25 \mathrm{~mm}$ inner diameter and $0.25 \mu \mathrm{m})$ ejector and detector whose temperature program was $190^{\circ} \mathrm{C}$ for $35 \mathrm{~min}$ then increased at $30^{\circ} \mathrm{C}$ per min up to $220^{\circ} \mathrm{C}$ where it was preserved for $5 \mathrm{~min}$. Hydrogen gas $\left(2 \mathrm{ml} \mathrm{min}^{-1}\right.$ and split ratio was $\left.30: 1\right)$ was used as carrier. By comparing their retention times and peak with a standard mix of FAs (Supelco 37 component FAME mix, catalogue No. 47885-U) the characteristic FAs were recognized and they were obtained in quantity (David et al., 2003).

Data were presented as mean \pm standard deviation (SD) and analysed by one-way analysis of variance (ANOVA). The significant means were compared by Duncan's multiple range tests at $\alpha=0.05$ level $(n=4)$.

\section{Results and discussion}

The major fatty acids of the oil extracted from the seeds of pepper (Capsicum annuum L.) cultivars are presented in Table 1 . The fatty acids content was significantly different among cultivars' seed samples. Palmitic (C16:0), oleic (C18:1n-9) and linoleic (C18:2n-6) acids were the highest in concentration followed by stearic acid $(\mathrm{C} 18: 0)$ at less than $5 \%$ and the other fatty acids at an even lower content $(<1 \%)$ in pepper cultivars.

The total saturated, mono-unsaturated, polyunsaturated and total oil contents were also different and shown in Table 2. Poly-unsaturated fatty acids ranged from $72.7 \%$ (cv. 'Yağ') to $77.8 \%$ (cv. 'Çetinel-150'); mono-unsaturated fatty acids ranged from 9.7\% (cv. 'Çetinel-150') to $12.7 \%$ (cv. 'Yağ'). In addition, pepper cultivars seed oils contained low amounts (12-14\%) of totally saturated fatty acids. There were no statistical differences between total oil content of pepper cultivars and composed nearly $16 \%$ across cultivars (Table 2 ).

Wide variations were determined among the contents of major fatty acids of tested seeds of cultivars. The total saturated, mono-unsaturated, poly-unsaturated fatty acids and total oil were also different. Some reports are available on the composition of fatty acids of pepper seeds from different regions of the world. For instance, Demir et al. (2008) and Embaby and Mokhtar (2011) suggested that linoleic acid was the most abundant fatty acid and constituted the maximum amount in total lipid content in pepper seeds. Pérez-Gálvez et al. (1999) similarly reported that the major fatty acids accumulated in the pepper seeds are palmitic, oleic, linoleic, and linolenic. Alike, Kaya et al. (2010) notified that the highest fatty acid of the seeds of pepper cultivars 'Çorbacı', 'Sera Demre 8' and 'Yalova Yağlık' was linoleic acid (78.9\%) followed by palmitic $(9.16-11.79 \%)$ and oleic $(7.28-11.40 \%)$. Also it was reported that oleic and palmitic acid contents of pepper seeds showed similar values, oleic acid content changed between $6.4 \%$ and $13.6 \%$ in fresh and between $9.3 \%$ and $10.7 \%$ in dried seeds. Plus, Jarret et al. (2013) indicated that the most abundant fatty acid of the tested Capsicum species was linoleic acid (73.92-77.93\%), followed by palmitic $(10.62-14.43 \%)$, oleic $(5.42-7.58 \%)$ and stearic (2.74-3.95\%) acids. Results of this work were similar and agreed with the above mentioned studies.

The data on germination percentage and vigour of the three pepper cultivars under different temperatures between $15^{\circ} \mathrm{C}$ and $35^{\circ} \mathrm{C}$ are presented in Table 3. Increasing temperature from $15^{\circ} \mathrm{C}$ to $35^{\circ} \mathrm{C}$ increased germination percentage and vigour across cultivars. However, there were no significant statistical differences for germination percentage of cv. 'Çetinel-150'. The lowest and highest 
Table 1. Fatty acid profile of two-year old pepper (Capsicum annuum L.) seeds (\%)

\begin{tabular}{|c|c|c|c|c|}
\hline \multirow{2}{*}{ Fatty acids* } & \multicolumn{4}{|c|}{ Cultivars } \\
\hline & \multicolumn{2}{|r|}{ 'Yağ' } & 'Çetinel-150' & 'Bağc1 Çarliston' \\
\hline C14:0 & 0.618 & $\pm 0.302 \mathrm{~ns}$ & $0.870 \pm 0.383$ & $0.524 \pm 0.139$ \\
\hline C14:1 & 0.064 & $\pm 0.052 \mathrm{~ns}$ & $0.073 \pm 0.016$ & $0.008 \pm 0.001$ \\
\hline C15:0 & 0.027 & $\pm 0.018 \mathrm{ab}$ & $0.051 \pm 0.017 \mathrm{a}$ & $0.009 \pm 0.001 \mathrm{~b}$ \\
\hline C15:1 & 0.093 & $\pm 0.049 \mathrm{a}$ & $0.093 \pm 0.001 \mathrm{a}$ & $0.034 \pm 0.006 \mathrm{~b}$ \\
\hline $\mathrm{C} 16: 0$ & 10.123 & $\pm 0.834 \mathrm{a}$ & $8.912 \pm 0.097 b$ & $10.656 \pm 0.072 \mathrm{a}$ \\
\hline C16:1n-7 & 0.311 & $\pm 0.005 \mathrm{a}$ & $0.214 \pm 0.009 \mathrm{~b}$ & $0.223 \pm 0.003 \mathrm{~b}$ \\
\hline $\mathrm{C} 17: 0$ & 0.134 & $\pm 0.042 \mathrm{~ns}$ & $0.094 \pm 0.075$ & $0.083 \pm 0.002$ \\
\hline $\mathrm{C} 17: 1$ & 0.178 & $\pm \quad 0.094 \mathrm{ab}$ & $0.249 \pm 0.011 \mathrm{a}$ & $0.090 \pm 0.065 \mathrm{~b}$ \\
\hline C18:0 & 2.844 & $\pm 0.470 \mathrm{~ns}$ & $2.284 \pm 0.008$ & $2.599 \pm 0.092$ \\
\hline C18:1n-9 & 10.420 & $\pm 0.669 \mathrm{a}$ & $7.616 \pm 0.211 b$ & $8.237 \pm 0.050 \mathrm{~b}$ \\
\hline C18:1n-7 & 0.767 & $\pm 0.146 \mathrm{~ns}$ & $0.901 \pm 0.041$ & $0.811 \pm 0.055$ \\
\hline $\mathrm{C} 18: 2 n-6$ & 72.719 & $\pm 0.688 \mathrm{c}$ & $77.869 \pm 0.148 \mathrm{a}$ & $75.638 \pm 0.049 \mathrm{~b}$ \\
\hline C20:1n-9 & 0.306 & $\pm \quad 0.029 \mathrm{ab}$ & $0.166 \pm 0.137 \mathrm{~b}$ & $0.438 \pm 0.054 \mathrm{a}$ \\
\hline $\mathrm{C} 22: 0$ & 0.793 & $\pm \quad 0.587 \mathrm{~ns}$ & $0.128 \pm 0.004$ & $0.377 \pm 0.004$ \\
\hline C22:1n-9 & 0.607 & $\pm 0.254 \mathrm{~ns}$ & $0.484 \pm 0.251$ & $0.277 \pm 0.051$ \\
\hline
\end{tabular}

Note. * - mean $\pm \mathrm{SD} ; \mathrm{C} 14: 0$ - miristic acid, C16:0 - palmitic acid, C16:1n-7 - palmitoleic acid, C17:0 - margaric acid, C18:0 stearic acid, C18:1n-9 - oleic acid, C18:2n-6 - linoleic acid, C20:1n-9 - gadoleic acid, C22:0 - behenic acid, C22:1n-9 - erucic acid; means with different letters on line are significantly different at $P=0.05$; ns - not significant.

Table 2. Saturated (SFA), mono-unsaturated (MUFA), poly-unsaturated (n-6 PUFA) fatty acids and total oil of twoyear old pepper (Capsicum annuum L.) seeds (\%)

\begin{tabular}{|c|c|c|c|}
\hline \multirow{2}{*}{ Fatty acids* } & \multicolumn{3}{|c|}{ Cultivars } \\
\hline & 'Yağ' & 'Çetinel-150' & 'Bağcı Çarliston' \\
\hline SFA & $14.538 \pm 0.356 \mathrm{a}$ & $12.337 \pm 0.184 \mathrm{~b}$ & $14.246 \pm 0.022 \mathrm{a}$ \\
\hline MUFA & $12.744 \pm 0.333 \mathrm{a}$ & $9.794 \pm 0.037 b$ & $10.117 \pm 0.071 \mathrm{~b}$ \\
\hline n-6 PUFA & $72.719 \pm 0.688 \mathrm{c}$ & $77.869 \pm 0.148 \mathrm{a}$ & $75.638 \pm 0.049 \mathrm{~b}$ \\
\hline Total oil & $16.029 \pm 0.177 \mathrm{~ns}$ & $16.567 \pm 0.166$ & $16.417 \pm 0.433$ \\
\hline
\end{tabular}

* - mean $\pm \mathrm{SD}$, means with different letters on line are significantly different at $P=0.05$; ns - not significant

germination percentages were determined for the seeds of The decrease in germination and vigour associated with cv. 'Yağ' $(22.65 \%)$ at $15^{\circ} \mathrm{C}$ and cv. 'Çetinel-150' (80.47\%) temperature was higher in 'Yağ' than the other cultivars, at $35^{\circ} \mathrm{C}$. Similarly, the lowest and the highest vigour and it can be said that cultivars varied in their temperature were obtained in the same cultivars and temperatures. requirement for germination and vigour.

Table 3. Mean seed germination and vigour of two-year old pepper (Capsicum annuum L.) seeds at various temperatures

\begin{tabular}{|c|c|c|c|c|}
\hline \multirow{3}{*}{ Temperature } & \multicolumn{4}{|c|}{ Cultivars } \\
\hline & 'Yağ' & 'Çetinel-150' & 'Bağcı Çarliston' & Mean \\
\hline & \multicolumn{4}{|c|}{ Germination \% } \\
\hline $15^{\circ} \mathrm{C}$ & $22.65 \mathrm{~b}^{* *}$ & $75.90 \mathrm{~ns}$ & $57.68 b^{*}$ & $52.08 \mathrm{~B}^{* *}$ \\
\hline $25^{\circ} \mathrm{C}$ & $62.39 \mathrm{a}$ & 79.54 & $68.73 \mathrm{ab}$ & $70.22 \mathrm{~A}$ \\
\hline $35^{\circ} \mathrm{C}$ & $68.05 \mathrm{a}$ & 80.47 & $75.81 \mathrm{a}$ & $74.78 \mathrm{~A}$ \\
\hline \multirow[t]{2}{*}{ Mean } & $51.03 \mathrm{C}^{* *}$ & $78.64 \mathrm{~A}$ & $67.41 \mathrm{~B}$ & \\
\hline & \multicolumn{4}{|c|}{ Vigour \% } \\
\hline $15^{\circ} \mathrm{C}$ & $17.94 b^{* *}$ & $63.12 \mathrm{c}^{* *}$ & $60.33 \mathrm{~b}^{* *}$ & $47.13 \mathrm{C}^{* *}$ \\
\hline $25^{\circ} \mathrm{C}$ & $54.13 \mathrm{a}$ & $68.30 \mathrm{~b}$ & $63.81 \mathrm{ab}$ & $62.08 \mathrm{~B}$ \\
\hline $35^{\circ} \mathrm{C}$ & $58.41 \mathrm{a}$ & $73.07 \mathrm{a}$ & $66.09 \mathrm{a}$ & $65.86 \mathrm{~A}$ \\
\hline Mean & $43.49 \mathrm{C}^{* *}$ & $68.16 \mathrm{~A}$ & $63.41 \mathrm{~B}$ & \\
\hline
\end{tabular}

* - significant at $P=0.05, * *$ - significant at $P=0.01, \mathrm{~ns}-$ not significant

Vegetable seeds that had high germination under optimal laboratory conditions and germination percentages of seeds under optimum conditions could give up to $90 \%$ germination. And, a complex metabolic process, germination of higher plants seeds as vegetables, involves many individual reactions and phases, each of which is affected by cardinal temperatures (Wanasundara et al., 1999; Copeland, McDonald, 2001). In other words, temperature is one of the most important environmental factors affecting seed germination and vigour. Plus, the germination of pepper is slow at room temperature, and further delayed by cooler $\left(15-18^{\circ} \mathrm{C}\right)$ conditions. Pepper required more time for radical emergence at $15^{\circ} \mathrm{C}$; however, germination was faster at $25^{\circ} \mathrm{C}$ and between $25^{\circ} \mathrm{C}$ and $35^{\circ} \mathrm{C}$ is the most appropriate temperature for germination of pepper types (Salk et al., 2008). Li et al. 
(2010) reported that germination was highest at $30^{\circ} \mathrm{C}$ and there was no germination at low temperatures. Next to the germination, vigour is affected by the temperature. Indeed, vigour took 8-9 days at temperatures from 25$35^{\circ} \mathrm{C}$ and was prevented altogether at temperatures lower than $15^{\circ} \mathrm{C}$ (Wien, 2002). Korkmaz (2005) reported that germination and vigour of pepper seeds were $44 \%$ and $40 \%$, respectively, at $15^{\circ} \mathrm{C}$. On the other hand, Demir et al. (2008) indicated that pepper seeds were given up to $70 \%$ germination at $25^{\circ} \mathrm{C}$ and the standard germination of pepper seed lots ranged from $85 \%$ to $95 \%$, while the vigour ranged from $76 \%$ to $94 \%$ at $15^{\circ} \mathrm{C}$ and $18^{\circ} \mathrm{C}$ (Kavak et al., 2008). Moreover, the germinability of vegetable seeds depends on many factors such as maturity, temperature, cultivar and species, etc. (Copeland, McDonald, 2001) and it was notified that environmental factors significantly influenced vigour (Kaymak, Güvenç, 2008). These differences are possibly associated with differences in temperature and cultivar characteristics and the results from this study confirmed these researchers' findings. The correlation coefficients between seed fatty acid profile, germination and vigour at various temperatures for all cultivars are shown in Table 4. Significant correlations were observed for the seed germination, vigour and fatty acids for all temperatures. Especially, palmitoleic (C16:1n-7) and oleic (C18:1n-9) acids were negatively and linoleic acid (C18:2n-6) was positively correlated with both germination and vigour for all temperatures. Similarly, while the total saturated and mono-unsaturated fatty acids were negatively correlated, total poly-unsaturated fatty acids and oil (except for $15^{\circ} \mathrm{C}$ and $25^{\circ} \mathrm{C}$ ) were positively correlated with both germination and vigour. In addition, a few positive or negative significant correlations with fatty acids such as stearic (C18:0) and behenic (C22:0), germination and vigour can be clearly seen in Table 4.

Table 4. Simple correlation coefficients $(r)$ among fatty acid profile, seed germination and vigour of pepper (Capsicum annuum L.) seeds at various temperatures

\begin{tabular}{|c|c|c|c|c|c|c|}
\hline \multirow{2}{*}{$\begin{array}{l}\text { Fatty } \\
\text { acids }\end{array}$} & \multicolumn{3}{|c|}{ Germination $\%$} & \multicolumn{3}{|c|}{ Vigour \% } \\
\hline & $15^{\circ} \mathrm{C}$ & $25^{\circ} \mathrm{C}$ & $35^{\circ} \mathrm{C}$ & $15^{\circ} \mathrm{C}$ & $25^{\circ} \mathrm{C}$ & $35^{\circ} \mathrm{C}$ \\
\hline C14:0 & $0.261 \mathrm{~ns}$ & $0.508 \mathrm{~ns}$ & $0.315 \mathrm{~ns}$ & $0.176 \mathrm{~ns}$ & $0.307 \mathrm{~ns}$ & $0.254 \mathrm{~ns}$ \\
\hline C14:1 & $-0.048 \mathrm{~ns}$ & $0.201 \mathrm{~ns}$ & $0.128 \mathrm{~ns}$ & $-0.253 \mathrm{~ns}$ & $-0.033 \mathrm{~ns}$ & $-0.034 \mathrm{~ns}$ \\
\hline C15:0 & $0.374 \mathrm{~ns}$ & $0.442 \mathrm{~ns}$ & $0.506 \mathrm{~ns}$ & $0.092 \mathrm{~ns}$ & $0.352 \mathrm{~ns}$ & $0.331 \mathrm{~ns}$ \\
\hline C15:1 & $-0.119 \mathrm{~ns}$ & $0.090 \mathrm{~ns}$ & $0.072 \mathrm{~ns}$ & $-0.356 \mathrm{~ns}$ & $-0.118 \mathrm{~ns}$ & $-0.151 \mathrm{~ns}$ \\
\hline C16:0 & $-0.461 \mathrm{~ns}$ & $-0.629 \mathrm{~ns}$ & $-0.565 \mathrm{~ns}$ & $-0.230 \mathrm{~ns}$ & $-0.469 \mathrm{~ns}$ & $-0.460 \mathrm{~ns}$ \\
\hline C16:1n-7 & $-0.929 * *$ & $-0.791 *$ & $-0.832 * *$ & $-0.998 * *$ & $-0.955 * *$ & $-0.900 * *$ \\
\hline $\mathrm{C} 17: 0$ & $-0.338 \mathrm{~ns}$ & $-0.458 \mathrm{~ns}$ & $-0.127 \mathrm{~ns}$ & $-0.508 \mathrm{~ns}$ & $-0.380 \mathrm{~ns}$ & $-0.491 \mathrm{~ns}$ \\
\hline C17:1 & $0.237 \mathrm{~ns}$ & $0.418 \mathrm{~ns}$ & $0.348 \mathrm{~ns}$ & $-0.018 \mathrm{~ns}$ & $0.237 \mathrm{~ns}$ & $0.151 \mathrm{~ns}$ \\
\hline C18:0 & $-0.688^{*}$ & $-0.640 \mathrm{~ns}$ & $-0.809 * *$ & $-0.593 \mathrm{~ns}$ & $-0.720 *$ & $-0.525 \mathrm{~ns}$ \\
\hline C18:1n-9 & $-0.927 * *$ & $-0.808 * *$ & $-0.912 * *$ & $-0.949 * *$ & $-0.961 * *$ & $-0.850 * *$ \\
\hline C18:1n-7 & $0.497 \mathrm{~ns}$ & $0.612 \mathrm{~ns}$ & $0.281 \mathrm{~ns}$ & $0.498 \mathrm{~ns}$ & $0.489 \mathrm{~ns}$ & $0.763 *$ \\
\hline C18:2n-6 & $0.961 * *$ & $0.882 * *$ & $0.935 * *$ & $0.907 * *$ & $0.979 * *$ & $0.919 * *$ \\
\hline C20:1n-9 & $-0.239 \mathrm{~ns}$ & $-0.595 \mathrm{~ns}$ & $-0.191 \mathrm{~ns}$ & $-0.091 \mathrm{~ns}$ & $-0.250 \mathrm{~ns}$ & $-0.491 \mathrm{~ns}$ \\
\hline C22:0 & $-0.680^{*}$ & $-0.659 \mathrm{~ns}$ & $-0.446 \mathrm{~ns}$ & $-0.683^{*}$ & $-0.663 \mathrm{~ns}$ & $-0.812 * *$ \\
\hline C22:1n-9 & $-0.367 \mathrm{~ns}$ & $-0.051 \mathrm{~ns}$ & $-0.219 \mathrm{~ns}$ & $-0.452 \mathrm{~ns}$ & $-0.332 \mathrm{~ns}$ & $-0.282 \mathrm{~ns}$ \\
\hline SFA & $-0.809 * *$ & $-0.860 * *$ & $-0.816^{* *}$ & $-0.624 \mathrm{~ns}$ & $-0.809 * *$ & $-0.817 * *$ \\
\hline MUFA & $-0.938 * *$ & $-0.772 *$ & $-0.890 * *$ & $-0.988 * *$ & $-0.966 * *$ & $-0.863 * *$ \\
\hline n-6 PUFA & $0.961 * *$ & $0.882 * *$ & $0.935^{* *}$ & $0.907 * *$ & $0.979 * *$ & $0.919 * *$ \\
\hline Total oil & $0.651 \mathrm{~ns}$ & $0.508 \mathrm{~ns}$ & $0.730^{*}$ & $0.671^{*}$ & $0.671^{*}$ & $0.695^{*}$ \\
\hline
\end{tabular}

* - significant at $P=0.05, * *$ - significant at $P=0.01$, ns - not significant; for abbreviations see Tables 1 and 2

Similar results were obtained in stepwise multiple regression analysis with the simple correlation coefficients (Table 5). In other words, near the direct effect of fatty acids, indirect effects of them on germination and vigour of pepper seeds were determined. Linoleic acid (C18:2n-6) was the principal fatty acid that affected the germination of pepper seeds according to the stepwise multiple regression analysis. And also, regression equations, $R$ square and other details for germination of pepper seeds are shown in Table 5. In addition, results for vigour may seem similar to germination, near to linoleic acid (C18:2n-6), the indirect effect of more fatty acids such as miristic (C14:0), margaric (C17:0), palmitoleic (C16:1n-7) and gadoleic (C20:1n-9) acids were determined for vigour. Regression equations, $R$ square and other details for vigour of pepper seeds are also given in Table 5.

Fatty acid composition had a significant effect on the germination percentage of the tested cultivars at various temperatures. The simple correlation coefficients and stepwise multiple regression analysis clearly revealed these results (Tables 4-5). Furthermore, it can be said that germination of pepper cultivars at various temperatures was closely related to extra or deficient endogenous fatty acids. Results of this study agree with previous studies owing to the fact that triglycerides, which are the major form of stored lipids in seeds, are hydrolyzed by lipases to diglycerides, monoglycerides, and then to glycerol and fatty acids (Krist et al., 2005). In other words, $\alpha$-oxidation plays a minor role in germinating seeds and $\beta$-oxidation plays a major role during germination period with the aid $\beta$-oxidase, yielding acetyl coenzyme A and energy in the form of adenosine triphosphate (ATP) (Copeland, McDonald, 2001). As is seen from Tables 5 and 6, palmitoleic acid (C16:1n-7), oleic acid (C18:1n-9), linoleic acid (C18:2n-6), total saturated and mono-unsaturated were correlated with both germination and vigour. Especially, linoleic acid (C18:2n-6) was effective on germination and vigour in all temperatures. Also, Wanasundara et al. (1999) and Theodoulou and Eastmond (2012) reported that during germination, storage lipids provide fatty acids that serve as an energy source to produce ATP and soluble carbohydrates for the growth of new cells. In addition to these reports, Kaymak (2012) showed that fatty acids and total oil content of seeds were significantly correlated with germination percentage and rate in cucurbits. 
Table 5. Stepwise multiple regression analysis of fatty acid profile and germination and vigour of pepper (Capsicum annuum L.) seeds at various temperatures

\begin{tabular}{|c|c|c|c|c|c|c|}
\hline \multirow{3}{*}{ Temperature } & & \multicolumn{2}{|c|}{ Unstandardized coefficients } & \multicolumn{2}{|c|}{ Standardized coefficients } & \multirow[b]{2}{*}{$P$ values } \\
\hline & & $B$ & Std. error & Beta & $t$ & \\
\hline & \multicolumn{6}{|c|}{ Germination \% } \\
\hline \multirow{2}{*}{$15^{\circ} \mathrm{C}$} & Constant & -717.294 & 83.548 & & -8.585 & 0.000 \\
\hline & C18:2n-6 & 10.203 & 1.107 & 0.961 & 9.212 & 0.000 \\
\hline \multicolumn{7}{|c|}{$\begin{array}{c}R \text { square }=0.913 \\
\mathrm{Y}=-717.294+(10.203 \times \mathrm{C} 18: 2 \mathrm{n}-6)\end{array}$} \\
\hline \multirow[b]{2}{*}{$25^{\circ} \mathrm{C}$} & Constant & -166.904 & 47.906 & \multirow[b]{2}{*}{0.882} & -3.484 & 0.010 \\
\hline & C18:2n-6 & 3.145 & 0.635 & & 4.952 & 0.002 \\
\hline \multicolumn{7}{|c|}{$\begin{array}{r}R \text { square }=0.746 \\
\mathrm{Y}=-166.904+(3.145 \times \mathrm{C}\end{array}$} \\
\hline \multirow{2}{*}{$35^{\circ} \mathrm{C}$} & Constant & -112.656 & 26.976 & \multirow[b]{2}{*}{0.935} & -4.176 & 0.004 \\
\hline & C18:2n-6 & 2.486 & 0.358 & & 6.951 & 0.000 \\
\hline \multicolumn{7}{|c|}{$\begin{array}{c}R \text { square }=0.855 \\
\mathrm{Y}=-112.656+(2.486 \times \mathrm{C} 18: 2 \mathrm{n}-6)\end{array}$} \\
\hline \multicolumn{7}{|c|}{ Vigour \% } \\
\hline \multirow{5}{*}{$15^{\circ} \mathrm{C}$} & Constant & 94.565 & 0.947 & & 99.833 & 0.000 \\
\hline & C16:1n-7 & -440.994 & 0.499 & -0.935 & -884.106 & 0.000 \\
\hline & C20:1n-9 & 12.048 & 0.084 & 0.077 & 143.213 & 0.000 \\
\hline & C18:2n-6 & 0.775 & 0.011 & 0.08 & 70.501 & 0.000 \\
\hline & C14:0 & 0.396 & 0.039 & 0.005 & 10.034 & 0.001 \\
\hline \multicolumn{7}{|c|}{$\begin{array}{c}R \text { square }=0.999 \\
\mathrm{Y}=94.565+(-440.994 \times \mathrm{C} 16: 1 \mathrm{n}-7)+(12.048 \times \mathrm{C} 20: 1 \mathrm{n}-9)+(0.775 \times \mathrm{C} 18: 2 \mathrm{n}-6)+(0.396 \times \mathrm{C} 14: 0)\end{array}$} \\
\hline \multirow{3}{*}{$25^{\circ} \mathrm{C}$} & Constant & -147.16 & 11.223 & & -13.112 & 0.000 \\
\hline & C18:2n-6 & 2.791 & 0.149 & 0.999 & 18.685 & 0.000 \\
\hline & C14:1 & -24.899 & 8.274 & -0.161 & -3.009 & 0.024 \\
\hline \multicolumn{7}{|c|}{$\begin{array}{c}R \text { square }=0.977 \\
\mathrm{Y}=-147.16+(2.791 \times \mathrm{C} 18: 2 \mathrm{n}-6)+(-24.899 \times \mathrm{C} 14: 1)\end{array}$} \\
\hline \multirow{5}{*}{$35^{\circ} \mathrm{C}$} & Constant & -127.668 & 1.265 & & -100.907 & 0.000 \\
\hline & C18:2n-6 & 1.915 & 0.019 & 0.657 & 101.027 & 0.000 \\
\hline & C18:1n-7 & 27.321 & 0.376 & 0.414 & 72.628 & 0.000 \\
\hline & Total oil & 1.659 & 0.122 & 0.087 & 13.656 & 0.000 \\
\hline & $\mathrm{C} 17: 0$ & -5.693 & 0.763 & -0.042 & -7.456 & 0.002 \\
\hline $\mathrm{Y}=$ & -10 & $2 n-6)+$ & $\begin{array}{l}\mathrm{e}=0.99 \\
\mathrm{C} 18: 1 \mathrm{n}-\end{array}$ & $9 \times$ tota & $(-5.693 \times$ & \\
\hline
\end{tabular}

For abbreviations see Tables 1 and 2

\section{Conclusions}

1. Linoleic acid (C18:2n-6) was the principal fatty acid followed by palmitic (C16:0), oleic (C18:1n-9) and stearic (C18:0) acids in the seed of all cultivars. The highest concentrations of linoleic $(77.8 \%)$, oleic $(10.4 \%)$, palmitic $(10.6 \%)$ and stearic $(2.5 \%)$ acids were determined in the seed of all cultivars 'Çetinel-150', 'Yağ' and 'Bağcı Çarliston', respectively.

2. All the tested pepper cultivars showed best performance at $35^{\circ} \mathrm{C}$ for germination percentage and vigour. The highest germination percentage $(80.47 \%)$ and vigour $\left(73.07 \%\right.$ ) were obtained in cv. 'C etinel- 150 ' at $35^{\circ} \mathrm{C}$.

3. The germination percentage and vigour of pepper cultivars were influenced by total oil and fatty acid profile of seeds of cultivars. The simple correlation coefficients showed that palmitoleic (C16:1n-7) and oleic (C18:1n-9) acids were negatively and linoleic acid (C18:2n-6) was positively correlated with both germination and vigour for all temperatures $\left(15,25\right.$ and $\left.35^{\circ} \mathrm{C}\right)$.

4. It was found that the most abundant (linoleic, palmitic, oleic and stearic) and the other (miristic, palmitoleic, margaric, gadoleic and behenics) fatty acids in the seeds of different pepper cultivars may play a major role in germination and vigour at various temperatures $\left(15,25\right.$ and $\left.35^{\circ} \mathrm{C}\right)$.

5. According to the results of stepwise multiple regression analysis, the role of linoleic acid $(\mathrm{C} 18: 2 n-6)$ in germination and vigour associated with temperature was more explicit than that of the other fatty acids.

\section{Acknowledgements}

The author would like to thank TUBITAK (The Scientific and Technological Research Council of Turkey), CAYDAG-105Y094, for establishing Gas Chromatography-Mass Spectrometry Laboratory in Atatürk University.

Received 04112013 Accepted 02062014

\section{References}

Barthet V. J. 2008. (n-7) and (n-9) cis-monounsaturated fatty acid contents of 12 Brassica species. Phytochemistry, 69 (2): $411-417$

http://dx.doi.org/10.1016/j.phytochem.2007.08.016

Copeland L., McDonald M. B. 2001. Seed germination. Copeland L. (ed.). Principle of seed science and technology ( $4^{\text {th }}$ ed. $)$, p. $72-124$

David F., Sandra P., Wylie P. L. 2003. Improving the analysis of fatty acid methyl esters using retention time locked methods and retention time databases. Application. $<\mathrm{http}: / / \mathrm{www}$. chem.agilent.com/Library/applications/5988-5871EN. pdf $>$ [accessed 11032014 ]

Decoteau R. D. 2000. Pepper. Linsner K. (ed.). Vegetable crops, p. $392-398$

Demir I., Tekin A., Okmen Z. A. Okçu G., Kenanoglu B. B. 2008. Seed quality, and fatty acid and sugar contents of pepper seeds (Capsicum annuum L.) in relation to seed development and drying temperatures. Turkish Journal of Agriculture and Forestry, 32 (6): 529-536

Embaby H. E., Mokhtar S. M. 2011. Chemical composition and nutritive value of lantana and sweet pepper seeds and nabak seed kernels. Journal of Food Science. 76 (5): 736-741 http://dx.doi.org/10.1111/j.1750-3841.2011.02166.x 
Folch J., Less M., Stanley G. H. S. 1957. A simple method for the isolation and purification of total lipids from animal tissues. The Journal of Biological Chemistry, 226 (1): 497-509

Güvenç I., Kaymak H. C. 2006. Suitability of boiling water test in prediction of seed viability of leek (Allium porrum) seeds. Indian Journal of Agricultural Science, 76 (7): 435-437

ISTA. 1996. International rules for seed testing. International Seed Testing Association, p. 179-180

Jarret R. L., Levy I. J., Potter T. L., Cermak S. C., Merrick L. C. 2013. Seed oil content and fatty acid composition in a genebank collection of Cucurbita moschata Duchesne and $C$. argyrosperma C. Huber. Plant Genetic Resources: Characterization and Utilization, 11 (2): 149-157 http://dx.doi.org/10.1017/S1479262112000512

Kavak S., Ilbi H., Eser B. 2008. Controlled deterioration test determines vigour and predicts field emergence in pepper seed lots. Seed Science and Technology, 36 (2): 456-461 http://dx.doi.org/10.15258/sst.2008.36.2.19

Kaya G., Demir I., Tekin A., Yaşar F., Demir K. 2010. Effect of priming treatment on germination at stressful temperatures, fatty acid, sugar content and enzymatic activity of pepper seeds. Journal of Agricultural Sciences, 16 (1): 9-16

Kaymak H. C. 2012. The relationships between seed fatty acids profile and seed germination in cucurbit species. Zemdirbyste-Agriculture, 99 (3): 299-304

Kaymak H. C., Güvenc I. 2008. The determination of the relations among the field emergence and physical properties and some laboratory tests of fresh bean (Phaseolus vulgaris L.) seeds. Journal Alata Horticultural Research Station, Alatarım, 7: 36-43. <http://www.alata.gov.tr/wp-content/ uploads/2012/05/13AlatarimHaziran2008.pdf> [accessed $31072014]$

Korkmaz A. 2005. Inclusion of acetyl salicylic acid and methyl jasmonate into the priming solution improves lowtemperature germination and emergence of sweet pepper. HortScience, 40 (1): 197-200

Krist S., Stuebiger G., Unterweger H., Bandion F., Buchbauer G. 2005. Analysis of volatile compounds and triglycerides of seed oils extracted from different poppy varieties (Papaver somniferum L.). Journal of Agricultural and Food Chemistry, 53 (21): 8310-8316 http://dx.doi.org/10.1021/jf0580869
Li Z., Liu A., Wu H., Tan L., Long Y., Gou Y., Sun S., Sang L. 2010. Influence of temperature, light and plant growth regulators on germination of black pepper (Piper nigrum L.) seeds. African Journal of Biotechnology, 9 (9): 1354-1358

Matthews S., Demir I., Celikkol T., Kenanoglu B. B., Mavi K. 2009. Vigour tests for cabbage seeds using electrical conductivity and controlled deterioration to estimate relative emergence in transplant modules. Seed Science and Technologv. 37 (3): 736-746 http://dx.doi.org/10.15258/sst.2009.37.3.20

Metcalfe L. D., Schmitz A. A. 1961. The rapid preparation of fatty acid esters for gas chromatographic analysis. Analytical Chemistry, 33 (3): 363-364 http://dx.doi.org/10.1021/ac60171a016

Mortley D. G., Oh, J. H., Johnson D. S., Bonsi C. K., Hill W. A. 2012. Influence of harvest intervals on growth responses and fatty acid content of purslane (Portulaca oleracea). HortScience, 47 (3): 437-439

Pérez-Gálvez A., Garrido-Fernández J., MínguezMosquera M. I., Lozano-Ruiz M., Montero-de-Espinosa V. 1999. Fatty acid composition of two new pepper varieties (Capsicum annuum L. cv. Jaranda and Jariza). Effect of drying process and nutritional aspects. Journal of the American Oil Chemists' Societv. 76 (2): 205-208 http://dx.doi.org/10.1007/s11746-999-0219-8

Salk A., Arin L., Deveci M., Polat S. 2008. Special vegetable cultivation $\left(1^{\text {st }}\right.$ ed. $)$

Sarıyıldız Z., Demir I., Halloran N. 2005. Germination at stress temperatures and ABA content of pepper (Capsicum annuит L.) seeds in relation to seed development. European Journal of Horticultural Science, 70 (2): 67-70

Theodoulou F. L., Eastmond P. J. 2012. Seed storage oil catabolism: a story of give and take. Current Opinion in Plant Biologv. 15 (3): 322-328

http://dx.doi.org/10.1016/j.pbi.2012.03.017

Wanasundara P. K. J. P. D., Wanasundara U. N., Shahidi F. 1999. Changes in flax (Linum usitatissimum L.) seed lipids during germination. Journal of the American Oil Chemists' Societv. $76(1): 41-48$ http://dx.doi.org/10.1007/s11746-999-0045-Z

Wien H. C. 2002. Peppers. Wien H. C. (ed.). The physiology of vegetable crops, p. 259-292

ISSN 1392-3196 / e-ISSN 2335-8947

Zemdirbyste-Agriculture, vol. 101, No. 3 (2014), p. 321-326

DOI 10.13080/z-a.2014.101.041

\title{
Vienametès paprikos (Capsicum annuum L.) veislių riebalų rūgščių profilių įtaka dygimui, priklausomai nuo temperatūros
}

\author{
H. Ç. Kaymak \\ Atatiurko universitetas, Turkija
}

\section{Santrauka}

Tyrimo tikslas - nustatyti veislių 'Yağ', 'Çetinel-150' ir 'Bağc1 Çarliston' vienametès paprikos sẻklų riebalų rūgščių profilius ir ryšius tarp jų, sėklų daigumo bei dygimo energijos, priklausomai nuo oro temperatūros $\left(15,25\right.$ ir $\left.35^{\circ} \mathrm{C}\right)$. Nustatyta ịvairių veislių paprikos sẻklų dygimo procentas ir dygimo energija, suminis aliejaus ir riebalų rūgščių profilis. Veislès labai skyrèsi sèklų daigumu ir dygimo energija. Visų veislių pagrindinè riebalų rūgštis buvo linolo (C18:2n-6), po to - palmitino (C16:0), oleino (C18:1n-9) ir stearino (C18:0) rūgštys. Veislių 'Çetinel-150', 'Yağ' ir 'Bağcı Çarliston' paprikose nustatytos didžiausios linolo (77,8\%), oleino $(10,4 \%)$, palmitino $(10,6 \%)$ ir stearino $(2,5 \%)$ rūgščių koncentracijos, o miristo, margarino, gadoleino ir beheno rūgščių koncentracijos buvo mažesnès $(<1 \%)$. Be nustatytų koreliacijos koeficientų $(r)$ tarp paprikos veislių suminio aliejaus riebalų rūgščių sudèties ir sèklų daigumo bei dygimo energijos, panašūs rezultatai gauti atlikus laipsnišką kartotinę regresinę analizę. Pagal šią analizę, nors sẻklų dygimo energijos rezultatai buvo panašūs ị linolo rūgšties priedo daigumo rezultatus, nustatyta netiesiogine miristo, margarino, palmitoleino ir gadoleino rūgščių įtaka sėklų dygimo energijai. Tyrimu rezultatai parodè, kad tirtų veislių paprikose maži arba dideli riebalų rūgščių kiekiai gali turèti lemiamos įtakos sėklų daigumui ir dygimo energijai esant įvairioms temperatūroms. Be to, linolo rūgšties (C18:2n-6) ịtaka sẻklų daigumui ir dygimo energijai esant ịvairioms temperatūroms buvo ryškesnè nei kitų riebalų rūgščių.

Reikšminiai žodžiai: daigumas, gyvybingumas, linolo rūgštis, Solanaceae, temperatūrų stresas. 